\title{
Świat jako zadanie dla inteligenta. \\ O dwóch wierszach Stanisława Barańczaka (Spójrzmy prawdzie w oczy, Grudzień 1976)
}

\begin{abstract}
Kopeć Zbigniew, Świat jako zadanie dla inteligenta. O dwóch wierszach Stanisława Barańczaka ("Spójrzmy prawdzie w oczy”, "Grudzień 1976”) [The world as a task for the intellectual. On two of Barańczak's poems (Let's face the truth, December 1976)]. „Przestrzenie Teorii" 26. Poznań 2016, Adam Mickiewicz University Press, pp. 131-138. ISSN 1644-6763. DOI 10.14746/pt.2016.26.7.

The analysis in this article focusses on two of Stanisław Barańczak's poems in the context of the writer's biography, i.e. the fact that he was an intellectual, poet, translator and essayist, as well as an opposition activist and one of the co-founders of the Workers' Defence Committee (Komitet Obrony Robotników). The starting point is a reference to Czesław Miłosz's essays entitled Life on the isles and Immorality of art, in which the Nobel prizewinner ponders the role of the poet in the contemporary world. The poems discussed in this article are presented as one of the possible forms through which the $20^{\text {th }}$-century ethos of the intellectual is realised.
\end{abstract}

Twórczość Barańczaka, bardzo wartościowa i różnorodna, doczekała się stosunkowo niedużej liczby opracowań - pisze Piotr Śliwiński ${ }^{1}$ chociaż równocześnie - dodajmy - Stanisław Barańczak od momentu debiutu, czy też debiutów, stawał się jednym z najważniejszych eseistów, poetów, tłumaczy i krytyków literackich XX i XXI wieku, a jego oddziaływanie intelektualne trudno przecenić. Poprzez tłumaczenie klasyki na język polski, ale także różnorodny współudział w tłumaczeniach polskiej literatury na języki obce, znany jest na całym świecie. Tych kilka oczywistych i lapidarnych uwag przypomina nie tylko o tym, że Stanisław Barańczak jest intelektualistą światowego formatu, skupionym na literaturze i w literaturze żyjącym, ale również i o tym, że w dużej mierze realizuje model intelektualisty określany przez Czesława Miłosza w eseju Życie na wyspach, jako poeta $\mathrm{w}$ todze polonisty (lub hispanisty, rusycysty i tak dalej”)2. Miłosz pisał, że taki model jest modelem przyszłości, a przecież był on realizowany i przez niego samego już w chwili, gdy powstał tekst, z którego pochodzi niniejszy cytat, i przez Stanisława Barańczaka. Pomimo tego, że obaj byli poetami $w$ togach, w dodatku poetami

${ }^{1}$ P. Śliwiński, Języki Stanistawa Barańczaka, [w:] Poeta i duch wolności. Szkice o twórczości Stanisława Barańczaka, red. P. Śliwiński, Poznań 2014.

2 C. Miłosz, Życie na wyspach, [w:] tenże, Życie na wyspach, Kraków 1977, s. 90. 
zaprzyjaźnionymi, jest między nimi kilka oczywistych i istotnych różnic. Skupię się na jednej. Miłosz rozpoczął studia polonistyczne na uniwersytecie Stefana Batorego w Wilnie w roku 1929, po czym szybko przeniósł się na prawo. Profesorem literatury został, mając za sobą karierę pracownika Polskiego Radia, dyplomaty, a przede wszystkim poety, pisarza, tłumacza i eseisty. Zatem najpierw był poetą, a potem został literaturoznawcą. W przypadku Stanisława Barańczaka sytuacja wyglądała inaczej. Jeśli nie brać pod uwagę „suchych” dat, w zasadzie trudno precyzyjnie określić, kto był pierwszy: Barańczak poeta? Barańczak tłumacz? Barańczak literaturoznawca, eseista?

Czesław Miłosz, przywołując opowiadanie Tomasza Manna pt. Tonio Kröger, pisze, że doświadczenia dwudziestowieczne wymagają od poezji ciągłej zmiany języka, którym artykułowane są najważniejsze problemy, co z kolei zmusza poetę do przyjęcia „chłodnej, wybrednej postawy”. „Buntowałem się w młodości przeciwko portretowi artysty, jaki znalazłem w opowiadaniu Tonio Kröger Tomasza Manna, przeciwko łączeniu działalności twórczej z neurozą i wewnętrznym spustoszeniem”3 - pisze Miłosz. Stwierdza jednak w innym miejscu, że „nawet przebrany za «normalnego» zjadacza chleba, ukrywający, kim jest naprawdę, artysta zawsze zdaje się mieć poczucie, że jest obcy, że przychodzi skądś z zewnątrz"4, czym - dodajmy - aktualizuje utrwaloną w kulturze opozycję „poeta i świat” - by przywołać tytuł powieści Józefa Ignacego Kraszewskiego. Podobne przeciwstawienie znaleźć można w poezji Stanisława Barańczaka, również w utworach, które są tu przedmiotem naszego zainteresowania, ze względu na to, że dokumentują poczucie obcości artysty, ukazując równocześnie jego zaangażowanie.

W Spójrzmy prawdzie w oczy „obcość”, o której pisze Miłosz, manifestuje się w takim usytuowaniu podmiotu należącego do zbiorowości czy też wspólnoty określanej w wierszu jako „my”, że odczuwa on swoją odrębność wobec tzw. zwykłego człowieka z miejskiego tłumu. W Grudniu 1976 bohater wiersza występuje jako tłumacz czy też, jeśli można tak powiedzieć, jako zawodowy intelektualista, który przerywa swoją pracę w pół słowa („na biurku czekał George Herbert, porzucony w pół rymu, ale co było robić"), by porozmawiać z robotnikiem-konspiratorem Olgierdem Krawczykiem. Dystans pomiędzy „poetą” a „zwykłym człowiekiem” jest wyraźny w obu utworach. W Spójrzmy prawdzie w oczy jest budowany przez cały wiersz. Tytułowe oczy należą do osób, których wspólną cechą jest samotność w tłumie podobnych do siebie ludzi i jakiś bliżej nie-

${ }^{3}$ C. Miłosz, Niemoralność sztuki, [w:] tenże, Życie na wyspach, s. 17.

${ }^{4}$ C. Miłosz, Życie na wyspach, s. 82. 
określony brak szczęścia, smutek, przygnębienie i zmęczenie, których przyczyny z wiersza trudno wyczytać, choć bez wątpienia podpowiada je historyczny kontekst. Nakaz czy też prośba patrzenia w oczy ponawiana $\mathrm{w}$ anaforycznej enumeracji w kolejnych wersach ani na moment nie zakłada, że spojrzenie zostanie odwzajemnione, tym samym niemożliwe jest dotarcie do duszy, człowieka, w którego oczy należy spojrzeć, ani, co równie ważne dla poety lingwisty ${ }^{5}$, nie zostanie nawiązany ani kontakt wzrokowy, ani żaden inny. Ci, którzy mają patrzeć w oczy, dzięki tym spojrzeniom wcale nie staną się automatycznie bliżsi tym, w których oczy mają spojrzeć. Wymienieni w wierszu „zwykli ludzie” są zbyt zajęci swoim życiem lub śmiercią.

Atmosfera obcości obecna jest również w utworze Grudzień 1976. Pracującego w zaciszu domowego mieszkania tłumacza (a również poetę, nauczyciela akademickiego, eseistę - przyjęcie perspektywy biografii autora utworu wydaje się tu „hipotezą konieczną”6) i Krawczyka Olgierda dzieli praktycznie wszystko. Aparycja i zwyczaje Krawczyka są na tyle różne od „inteligenckich” i charakterystyczne, że nawet po latach mogą zostać przypomniane: „zawsze musiał najpierw się rozsiąść, rozetrzeć w popielniczce zżółkłego peta, przedmuchać jak się patrzy szklaną lufkę, pogadać przez pół godziny o lidze piłkarskiej [...] bez górnych siekaczy, $\mathrm{w}$ wiecznej kurtce $\mathrm{z}$ zielonej dermy, $\mathrm{z}$ baczkami na cały policzek [...] Chrzęst kurtki, czerń smaru czy farby wokół paznokcia kciuka”. W utworze nie ma mowy o „inwazyjności” tej wizyty, ale nagromadzenie głoski „r" podkreśla dysonans, czy też może raczej: niepokój czy napięcie, jakie wizyta ta wnosi (pojawiają się już w imieniu i nazwisku gościa, chrzęście kurtki, czerni smaru). I w tym przypadku porozumienie jest niemożliwe, ponieważ brakuje „wspólnych słów”, które umożliwiłyby autentyczne porozumienie. Bohater wiersza w zakłopotaniu skorzystać może tylko z tych, które podpowiada konwenans i które będąc „płytsze, umowne, oględne”, nie muszą znaczyć wiele, choć są potrzebne: „Spokojna głowa; nie ma się co martwič; „Poradzimy sobie z tym wszystkim”. Nie jest to objaw lekceważenia rozmówcy, ale przejaw niemocy i bezradności, a chyba też i przekonania, że prawdziwe porozumienie pomiędzy intelektualistą a robotnikiem (a może między ludźmi w ogóle), jeśli nie jest niemożliwe, to $\mathrm{z}$ całą pewnością nie jest łatwe.

5 Zob. T. Cieślak-Sokołowski, Moment lingwistyczny. O wczesnym pisarstwie Ryszarda Krynickiego i Stanistawa Barańczaka, Kraków 2011.

${ }^{6}$ Zob. J. Ziomek, Autobiografizm jako hipoteza konieczna („Treny” Jana Kochanowskiego), [w:] tenże, Powinowactwa literatury. Studia i szkice, Warszawa 1980. Na dominującą rolę biografii autora w tym i innych utworach Stanisława Barańczaka zwraca uwagę Dariusz Pawelec. Zob. D. Pawelec, Poezja Stanisława Barańczaka, Katowice 1992, s. 154 oraz tenże, Czytając Barańczaka, Katowice 1995, s. 154-156. 
Utwór Spójrzmy prawdzie $w$ oczy pochodzi z tomu Jednym tchem z roku 1970, na którego powstanie musiała mieć wpływ ogólna atmosfera końca lat sześćdziesiątych, a również wydarzenia marca 1968 roku. Utwór Grudzień 1976 już poprzez tytuł odwołuje się do roku 1976, kiedy rząd Piotra Jaroszewicza podjął próbę wprowadzenia drastycznej podwyżki cen i konsekwencji tych wydarzeń: społecznych protestów, a potem represji wobec robotników biorących udział w wydarzeniach m.in. w Radomiu i Ursusie, a w efekcie powstania Komitetu Obrony Robotników. Usytuowanie tego wiersza w porządku biografii Barańczaka jest zatem w pełni uzasadnione. Robotnik przychodzi do członka KOR-u i redaktora „Biuletynu Informacyjnego «KOR»” (,zamieścimy w «Biuletynie» notatkę") po podziemne druki i słowa otuchy. Dostaje jedno i drugie, a po latach rozbudowana refleksja na temat tego wydarzenia pojawia się $\mathrm{w}$ jednym $\mathrm{z}$ wierszy Widokówki $z$ tego świata, tomiku bardzo różnym od Jednym tchem, napisanym w Ameryce i wydanym w roku 1988, a więc w miejscu i czasie daleko innym niż Polska z czasów rządów Gomułki i Gierka.

Stanisław Barańczak, pisząc o roli poezji w słynnym eseju pt. Zmieniony głos Settembriniego ${ }^{7}$, powołuje się, podobnie jak Miłosz, na Tomasza Manna, ale w jego przypadku jest to Czarodziejska góra, dzieło o ponad dwadzieścia lat późniejsze od Tonio Krögera i znacznie dojrzalsze. Fundamentem swoich wywodów Barańczak czyni postawę i światopogląd jednego z bohaterów tej powieści. Dla Barańczaka w roku 1975 wybór Settembriniego mógł być o tyle oczywisty, że jego postawa w utworze Manna jest przeciwstawiona Naphcie - zwolennikowi terroru i prawd jedynych, opartych na zewnętrznym autorytecie, z którym Włoch walczy o duszę i rozum Hansa Castorpa, niemieckiego głuptaska ${ }^{8}$.

Daleko jednak z tego miejsca do twierdzenia, że Miłosz i Barańczak zajmują od siebie odległe stanowiska, jeśli idzie o rolę poety i poezji w świecie. Spośród galerii mannowskich postaci Miłosz wybrać mógł bohatera, którego modernistyczno-artystowska postawa jest jeszcze bardziej wyrazista, np. główną postać Doktora Faustusa, utworu wydanego $\mathrm{w}$ dwa lata po zakończeniu drugiej wojny światowej, ale, co znamienne, poeta, już w „todze slawisty”, powrócił do przemyśleń z lat trzydziestych - lat poetyckich i nie tylko poetyckich buntów. Młody Miłosz sprzeciwiał się postawie artystowskiej zaprezentowanej w opowiadaniu Manna,

7 S. Barańczak, Zmieniony głos Settembriniego, [w:] tenże, Etyka i poetyka. Szkice 1970-1978, Paryż 1979.

8 E. Pieciul, Symbolika nazw osobowych w „Czarodziejskiej górze”, „Polonistyka” 2003, nr 2, s. 80. 
a równocześnie zaczytywał w „konkursowych” reportażach drukowanych w redagowanym przez Aleksandra Wata komunistycznym „Miesięczniku Literackim"9, w których eksponowano trudne warunki pracy i życia polskiego proletariatu. Podobna lewicowa wrażliwość przyczyniła się do tego, że Barańczak działa w opozycji, jest w gronie założycieli KOR, podejmuje liczne akcje o charakterze protestacyjnym. Jerzy Kandziora w znakomitej książce pt. Ocalony w gmachu wiersza. O poezji Stanistawa Barańczaka podkreśla kluczową dla poezji pokolenia 1968 tradycję awangardową, wskazując szczególnie na poezję ekspresjonistów i żagarystów. Badacz zwraca uwagę na podobne ujęcia wątków związanych $\mathrm{z}$ ciałem w twórczości poetów awangardowych i nowofalowców oraz ich lewicowe konteksty, nie pomijając równocześnie problematyki społecznej obecnej w twórczości ekspresjonistów i żagarystów (a wspomnieć też trzeba również np. o „Reflektorze” i związanym z nim Czechowiczem oraz kwadrygantach). Za świadectwo tej wrażliwości można uznać wypowiedź Barańczaka z 1974 roku, zwracającego uwagę na znaczenie dla jego poetyckiego pokolenia wydarzeń z marca 1968 i grudnia 1970: „to właśnie marzec był dla tej generacji właściwym «przeżyciem pokoleniowym»; grudzień był tylko (choć słowo «tylko» może nie jest na miejscu wobec tej tragedii) potwierdzeniem uprzedniej diagnozy"10.

Społeczna wrażliwość cechowała wiele postaci historycznych - kilka $\mathrm{z}$ nich opisuje Bohdan Cywiński w Rodowodach niepokornych ${ }^{11}$ - i wielu bohaterów literackich: dość będzie, jeśli się wspomni choćby doktora Tomasza Judyma czy, w ostatecznym rachunku, Cezarego Barykę z prozy Stefana Żeromskiego. Dzięki nim Żeromski stworzył wzorzec bohatera-inteligenta. Człowieka, który nie tylko jest gotowy rozpatrywać swoje życie w kategoriach misji, niosąc pomoc potrzebującym, zastępując w tym państwowe instytucje (np. szkołę, szpital), ale też sytuuje się pomiędzy władzą a społeczeństwem, przyjmując na swoje barki rolę mediatora i obrońcy tych, którzy sami bronić się nie potrafią. Lidia Burska w bardzo ważnej książce ukazującej pokolenie '68 we wszystkich możliwych perspektywach do tego zacnego, choć niestety, staroświeckiego dziś grona zalicza również Stanisława Barańczaka. Pisząc o tomiku Jednym tchem, z którego pochodzi wiersz Spójrzmy prawdzie w oczy, stwierdza: „Był on zapisem sytuacji psychicznej i egzystencjalnej, w jakiej znalazł się młody

9 A. Wat, Mój wiek. Pamiętnik mówiony. Część pierwsza, rozmowy prow. i przedm. opatrzył C. Miłosz, Warszawa 1990, s. 58.

10 F. Niedolski [S. Barańczak], Stowo wstępne, Jacek Berezin, Wam. Poezje, Paryż 1974. Cyt. za S. Barańczak, Etyka i poetyka..., s. 185.

11 B. Cywiński, Rodowody niepokornych, Kraków 1971. 
inteligent po Marcu"12. W jej stwierdzeniu kryje się odpowiedź na pytania Joanny Dembińskiej-Pawelec postawione pod koniec bardzo ciekawej interpretacji wiersza Spójrzmy prawdzie w oczy: „Otwartym wciąż pytaniem, nad którym warto $\mathrm{w}$ tym wierszu się zastanowić, jest: Kto, o kim i do kogo się zwraca? Relacja rysuje się następująco: zbiorowość obserwuje zbiorowość i wydaje sobie (zbiorowości) nakazy do wykonania"13. Joanna Dembińska-Pawelec odpowiada na to pytanie, przywołując romantyczną koncepcję lustrzanych odbić14, ale myślę, że tę odpowiedź warto zmodyfikować. Ma rację bowiem Lidia Burska, pisząc, że Stanisław Barańczak i inne postacie należące do KOR-u i wielu innych organizacji, których tu nawet nie będę próbował wymieniać, bo absolutnie nie sposób tego zrobić, bez wątpienia zasługują na miano inteligentów, którym wydarzenia marcowe, a potem grudniowe musiały uświadomić, że realizowany w Polsce projekt nowoczesności, zakładający postęp manifestujący się ciągłą poprawą warunków życia nie ma absolutnie szans na realizację, a państwo nazywające się robotniczo-ludowe postawiło się po przeciwnej stronie barykady niż robotnicy.

W Spójrzmy prawdzie $w$ oczy Barańczak po mistrzowsku prowadzi utwór do puenty. Wylicza „oczy”, będące synekdochą „zwykłych ludzi”, w które trzeba spojrzeć , by w drugiej części wiersza, rozpoczynającej się do średnika, zmienić imperatyw z „spójrzmy w oczy” (czyli na człowieka), na: „dajmy z siebie wszystko” [,zwykłym ludziom” - Z.K.]. Dlaczego należy dać „z siebie wszystko na własność tym spojrzeniom” i dlaczego należy porzucić „w pół rymu” tłumaczenie Georga Herberta? Powodów jest co najmniej kilka. Po pierwsze, pomimo tego, że bohater wierszy Barańczaka często, choć nie zawsze, odczuwa swoją odrębność wobec tłumu, to równocześnie w jego poezji jest obecne wyraźne i nieredukowalne przekonanie o wspólnocie wszystkich ludzi, bez względu na wiek, zawód, przyzwyczajenia czy status społeczny. To przekonanie jest oparte na wspólnym doświadczaniu życia i śmierci, historii i ciała. Dobrym przykładem może tu być wiersz pt. Czterdzieści osiem, w którym bohater pyta, powątpiewając, czy może coś łączyć go (działacza, opozycjonistę, „zakazanego” poetę) i współosadzonych: „robociarza w kitlu (kradzież narzędzi) [...] waluciarza w kożuchu (zakłócenie spokoju w stanie wskazującym)".

${ }^{12}$ L. Burska, Awangarda i inne złudzenia. O pokoleniu '68 w Polsce, Gdańsk 2012, s. 110.

13 J. Dembińska-Pawelec, Między Bogiem a prawdą. Spójrzmy prawdzie w oczy Stanistawa Barańczaka, [w:] Kanonada. Interpretacje wierszy polskich (1939-1989), red. A. Nawarecki, przy współudziale D. Pawelca, Katowice 1999, s. 143.

14 Tamże. 
Okazuje się, że tak. Tym, co łączy, jest wspólne przerażenie złem i cierpieniem:

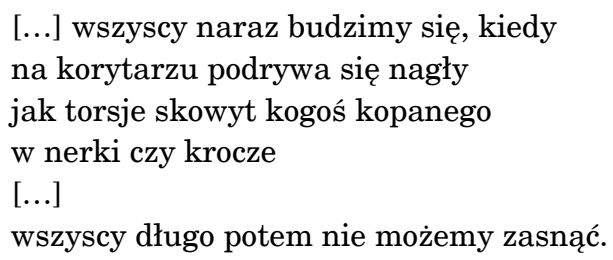

Po drugie, „prawda”, której Barańczak nie definiuje, rozumiejąc ją intuicyjnie (podobnie jak w niniejszych rozważaniach rozumiane jest pojęcie „inteligent”15), jest wartością, o którą warto zabiegać i której należy poszukiwać, zwłaszcza w sytuacji, gdy oficjalny język robi wszystko, by ją zmistyfikować. To dlatego w utworze Spójrzmy prawdzie w oczy Barańczak korzysta z metody polegającej na przywracaniu znaczenia słowom czy związkom frazeologicznym, jaką zastosował w wielu innych utworach, $\mathrm{np}$. Złożyli wieńce $i$ wiązanki kwiatów ${ }^{16}$.

I w końcu po trzecie, Stanisław Barańczak został inteligentem, ukształtowany przez etos polskiej inteligencji z końca XIX i początkowych lat XX wieku, który stawiał przed „ludźmi nauki i talentu” świat jako zadanie do wypełnienia. Wypełnić można je jedynie poprzez społeczną służbę.

\section{BIBLIOGRAFIA}

Barańczak S., Zmieniony głos Settembriniego, [w:] S. Barańczak, Etyka i poetyka. Szkice 1970-1978, Paryż 1979.

Bolecki W., Język jako świat przedstawiony. O wierszach Stanisława Barańczaka, [w:] W. Bolecki, Pre-teksty i teksty, Warszawa 1998.

Burska L., Awangarda i inne złudzenia. O pokoleniu '68 w Polsce, Gdańsk 2012.

Cieślak-Sokołowski T., Moment lingwistyczny. O wczesnym pisarstwie Ryszarda Krynickiego i Stanisława Barańczaka, Kraków 2011.

Cywiński B., Rodowody niepokornych, Kraków 1971.

Czepulis-Rastenis R., Ludzie nauki i talentu. Studia o świadomości społecznej inteligencji polskiej w zaborze rosyjskim, Warszawa 1988.

${ }^{15} \mathrm{Na}$ niemożliwość wskazania „zgodnych ustaleń ani co do zakresu omawianej kategorii społecznej i czasu jej powstania, ani też głównych funkcji i dążeń, które miałyby stanowić jej cechy specyficzne”. R. Czepulis-Rastenis, Ludzie nauki i talentu. Studia o świadomości społecznej inteligencji polskiej w zaborze rosyjskim, Warszawa 1988, s. 6.

16 Zob. W. Bolecki, Język jako świat przedstawiony. O wierszach Stanisława Barańczaka, [w:] tenże, Pre-teksty i teksty, Warszawa 1998, s. 217. 
Dembińska-Pawelec J., Między Bogiem a prawda. Spójrzmy prawdzie w oczy Stanistawa Barańczaka, [w:] Kanonada. Interpretacje wierszy polskich (1939-1989), red. A. Nawarecki, przy współudziale D. Pawelca, Katowice 1999.

Miłosz C., Niemoralność sztuki, [w:] C. Miłosz, Życie na wyspach, Kraków 1977.

Miłosz C., Życie na wyspach, [w:] C. Miłosz, Życie na wyspach, Kraków 1977.

Niedolski F., [S. Barańczak], Stowo wstępne, Jacek Berezin, Wam. Poezje, Paryż 1974.

Pawelec D., Czytając Barańczaka, Katowice 1995.

Pawelec D., Poezja Stanistawa Barańczaka, Katowice 1992.

Pieciul E., Symbolika nazw osobowych w „Czarodziejskiej górze”, „Polonistyka” 2003, $\mathrm{nr} 2$.

Śliwiński P., Języki Stanisława Barańczaka, [w:] Poeta i duch wolności. Szkice o twórczości Stanisława Barańczaka, red. P. Śliwiński, Poznań 2014.

Wat A., Mój wiek. Pamiętnik mówiony. Część pierwsza, rozmowy prow. i przedm. opatrzył C. Miłosz, Warszawa 1990.

Ziomek J., Autobiografizm jako hipoteza konieczna („Treny” Jana Kochanowskiego), [w:] J. Ziomek, Powinowactwa literatury. Studia i szkice, Warszawa 1980. 